\title{
CAREER DEVELOPMENT THEORIES FOR THE EDUCATION OF UNEMPLOYED
}

\author{
Gita Stalidzāne
}

Latvia University of Agriculture, Jelgava, Latvia

\begin{abstract}
The topicality of the research - To determine the tendencies of the development of career services, conclusions of career theories have been analysed in the article, the career promoting and hindering factors in the State Employment Agency have been investigated, which could help to employ the forms, methods and techniques of pedagogical organization thus creating preconditions for a more successful career development of the clients. The aim of the research - to explore the career theories, which can be used for the unemployed to obtain their education or to improve their motivation according to the economic situation. Career development theories such as career development structural or opportunity theories (J.Klimov, J.Parson, J.Holland, K.G.Jung) and development or lifespan theories (D.Super, L.Ginsberg, R.Havighurst, E.Erikson, J.Krumbolz, A.Bandura, Dh.Fukuyama) were investigated. In the changing conditions of economics new requirements for the working people are being developed because of formation of new forms of employment. The former advantage in Latvia - the relevantly cheap labour force, has already ceased to exist, so in the future it will not be able to serve as the resource for the economical development. In the formation of an educated society only purposeful educational action can ensure the development and prosperity of the state, so enabling the individuals to find creative solutions in critical situations and adapt in a new environment. The main problem is the contradiction between the acquisition of the value of education in the adult society and the fact that the unemployed in adult age have the lack of knowledge for making their career. Everybody has a different career, it is developing dynamically all through the lifetime. The career reflects the skill of the individual to find balance between the salaried work and the unpaid work, as well as the duties of the personal life.
\end{abstract}

Keywords: adult education, career, career counselling, career development theories, unemployed.

\section{Introduction}

In the time of rapid changes, which are being observed in all the spheres of human life right now, there is increasing cooperation between the European countries, which is affected by the global development tendencies. Alongside with that also the comprehension about education and occupation is changing. Nowadays due to the influence of globalisation processes education becomes more and more important and diverse. In the adult education there appear new forms and methods of teaching and learning to make the process of acquiring new knowledge and skills more effective. The European Union Lifelong Learning programme offers an opportunity for collaboration to State Employment Agency, educational establishments, local authorities, entrepreneurs as well as social organisations. In the White Book of the European 
Commission it is indicated that a learning-focused network must be formed (EC, 1998).

This article describes the research about the improvement of a person's career development. In the changing economic circumstances there develop new requirements for the employees, as new forms of employment and new work places are being created. The previous advantage in Latvia - comparatively cheap labour force - has already lost its topicality, and in the future it will not be able to serve as a resource for the economic development. The professional improvement according to different stages of human life has been analysed by different theories of career development (Mikelsone, Latsone, 2008). The registered level of unemployment in the state at the end of December, 2014 was $8.5 \%$ (the proportion of the registered unemployed from the total of economically active inhabitants). The lowest level of unemployment in December, 2014 was registered in Riga region - 5.2\%, the highest level of unemployment was in Latgales region $-17.8 \%$. In Kurzemes region the level of unemployment was $10.7 \%$, Zemgales region $-8.3 \%$ and Vidzemes region 9.9\%. In December, in comparison with the previous month, the level of unemployment in Kurzemes region increased by $0.7 \%$ points, Vidzemes and Zemgales region by $0.3 \%$ points, in Latgale - by $0.2 \%$ points, but in Riga the level.

For lifelong learning and career education in Latvia it is important to ensure opportunities for everybody to acquire appropriate professional skills, education and preparation for a successful participation in the labour market (The assessment of the activity of the career development support system in Latvia, 2013).

Table 1. The division of the unemployed according to the obtained education, $\%$

\begin{tabular}{|c|c|c|c|c|c|}
\hline \multicolumn{3}{|l|}{2013} & \multicolumn{3}{|l|}{2014} \\
\hline $\begin{array}{l}\text { Unemployed } \\
\text { according to the } \\
\text { obtained } \\
\text { education }\end{array}$ & Female & Male & $\begin{array}{l}\text { Unemployed } \\
\text { according to the } \\
\text { obtained } \\
\text { education }\end{array}$ & Female & Male \\
\hline $\begin{array}{l}\text { Higher education } \\
(14,0 \%)\end{array}$ & 9277 & 3831 & $\begin{array}{l}\text { Higher education } \\
(14,9 \%)\end{array}$ & 8702 & 3496 \\
\hline $\begin{array}{l}\text { Vocational } \\
\text { training(37,3\%) }\end{array}$ & 18131 & 16720 & $\begin{array}{l}\text { Vocational } \\
\text { training }(37,1 \%)\end{array}$ & 15376 & 15042 \\
\hline $\begin{array}{l}\text { General } \\
\text { secondary } \\
\text { education } \\
(26,6 \%)\end{array}$ & 14239 & 10614 & $\begin{array}{l}\text { General } \\
\text { secondary } \\
\text { education } \\
(26,3 \%)\end{array}$ & 12172 & 9431 \\
\hline $\begin{array}{l}\text { Elementary } \\
\text { education } \\
(19,2 \%)\end{array}$ & 9293 & 8614 & $\begin{array}{l}\text { Elementary } \\
\text { education } \\
(18,9 \%)\end{array}$ & 8020 & 7476 \\
\hline
\end{tabular}


From the total of the registered unemployed in Latvia at the end of December, 2014 the biggest proportion was made by the unemployed with the vocational training - 37.1\%, and, in comparison with the end of 2013, this indicator has decreased by $0.2 \%$ points, however, the proportion of the unemployed with the higher education has increased by $0.9 \%$ points from $14.0 \%$ at the beginning of the year until $14.9 \%$ at the end of December (www.csb.gov.lv).

The current level of unemployment is mainly connected with the cyclic unemployment, i.e. with the decrease of the essential amount of production and the provided services during the crisis. Thus all the activities which are connected with the promotion of the economic activities and entrepreneurship, stimulate the increase of the demand for the labour force and increase employment. At the same time there is a risk that one part from the existing unemployed will be unable to find a job for a long time, so in the future unemployment can become an explicitly structural phenomenon (EM informative announcement ,About the medium and long-term predictions of the labour market", 2014)

The International Labour Organization, according to its calculations, estimate that the world level of unemployment will increase and by 2019212 million people will become unemployed. In January, 2015201 million people are unemployed worldwide. The organization points out that a big part of young people aged $15-24$ will experience difficulties in finding a job. The world unemployment level in this age group reaches $13 \%$, and, as the document states, this indicator is going to increase. The consequences of the crisis in the international labour market have not been overcome, it is necessary to make an effort to fight with unemployment and its consequences also further on (International Labour Conference session No 102 and the announcement of the Social Dialogue Committee, 2013).

The strategy of a sustainable development of Latvia until 2030 indicates that innovative economics requires more and more new skills and competences from the employees to be able to adapt to the changing labour market requirements. However, the system of education of Latvia is not flexible enough in solving the needs of adult further education. It means that the competitiveness of Latvia will more and more depend on the link of the system of education with the changes in the labour market and the ability to prepare the person for the job in changing circumstances throughout the lifetime. (The strategy of a sustainable development of Latvia until 2030, LR Saeima, 2010).

The EU Council Resolution suggests the basic initiatives of Strategy "Europe 2020" so that the adults, especially those who are low-skilled or elderly, could improve their ability to adapt to the new requirements of labour market and society. The adult education gives opportunities to improve or adapt the skills of those people who have been affected by unemployment, as well as essentially promotes the social inclusion (The Council Resolution about a 
renewed European programme of education for the adults, EU Official Journal, 2011).

The education development guidelines for the years $2014-2020$ is a medium-term policy planning document, which states the basic principles, aims and spheres of activity of the education development policy for the next seven years. The processes of education directly concern every inhabitant in all age groups, the guidelines comprise all kinds and levels of education (LR Saeima, The Education Development Guidelines for years 2014 - 2020, 2014).

Professor Tatyana Koke stresses that the adult education must promote the increase of life quality. Everybody must look for and ensure new, more effective ways of learning, flexibly combining the resources, attracting partners for cooperation and expanding the educational environment (Kokse, 1999).

The adult education helps to shift accents from stable education to flexible one, the basis of which is general knowledge, offering and solving the issues of curriculum in an integrated way, making it more real-life like (Koke, 2011).

The aim of the research is to investigate and identify the career development theories, which would be appropriate to use for promoting the unemployed to obtain education or promote the motivation of personal improvement according to the economic situation.

\section{Methodology of Research}

The research was carried out in the State Employment Agency, as well as in the State Employment Agency Jēkabpils branch in 2014 by an electronic survey of 3468 unemployed and job seekers about the opportunities of education for the career development.

Theoretical methods have been used for the research - studying, analysis and evaluation of the scientific literature, surveys, researches and documents. To carry out the tasks, the stages of the research were identified, analysed and evaluated. For the analysis different scientific theories were chosen which deal with the factors influencing the career - developmental theories of vocational behaviour or life-span theory (D.Super, E.Erikson) (Super, 1990); the structural theory or the theory of occupational allocation (J.Klimov, J.Holland) (Holland, 1997); the theory of rational choice of profession by Sh.Fukuyama; the cycle theory of development tasks throughout the lifetime (M.Savickas) (Savickas, 2005); socio-dynamic constructivist theories (R.Vance Peavy) (Peavy, 2010). Also the theory and practice of the research methodology, alongside with the previous research conducting experience of the author of the research, were taken into consideration.

Specialists, who work in the sphere of career education, by maintaining a common understanding about a human and its development through different stages of life, have to take into consideration that the personality is influenced by the environment, culture and experience (Korna, 2011). 
The major part of the career theories look at the career influencing factors mainly from the viewpoint of the career counsellor. By integrating the career theory conclusions into the science of pedagogy, by identifying the promoting and the inhibiting factors of the career, during the process of the employment agency services it becomes possible to look for and make use of those pedagogical organization forms and methods, which would ensure the formation of certain habits of activities, thus creating pedagogical preconditions for a more successful career development.

Rasma Garleja in her „Human Potential in a Social Environment” states that „Career opportunities according to McClelland theory serve as a success motivating factor, as the behaviour determining factor, as a human potential creating factor (a wish to know, be able to, risk). Career is the motivation of achievement, it is self-control, dedication, self-confidence. It is an important self-realization process, followed by social recognition (Garleja, 2006).

\section{Results of the research}

To evaluate the satisfaction of the unemployed and job seekers with the service provided by State Employment Agency and also Jēkabpils branch, during the year 2014 a survey of the unemployed and job seekers was carried out about their satisfaction with the services of the Agency. The aim of the evaluation of the satisfaction is a constant improvement of the Agency actions and provision of an effective customer-focused service system regardless of the place of the service. Within the survey 3468 unemployed and job seekers were questioned. As it is seen in the results of the survey, $72 \%$ of all the questioned are women, and $28 \%$ - men. Women have been most active in the survey.

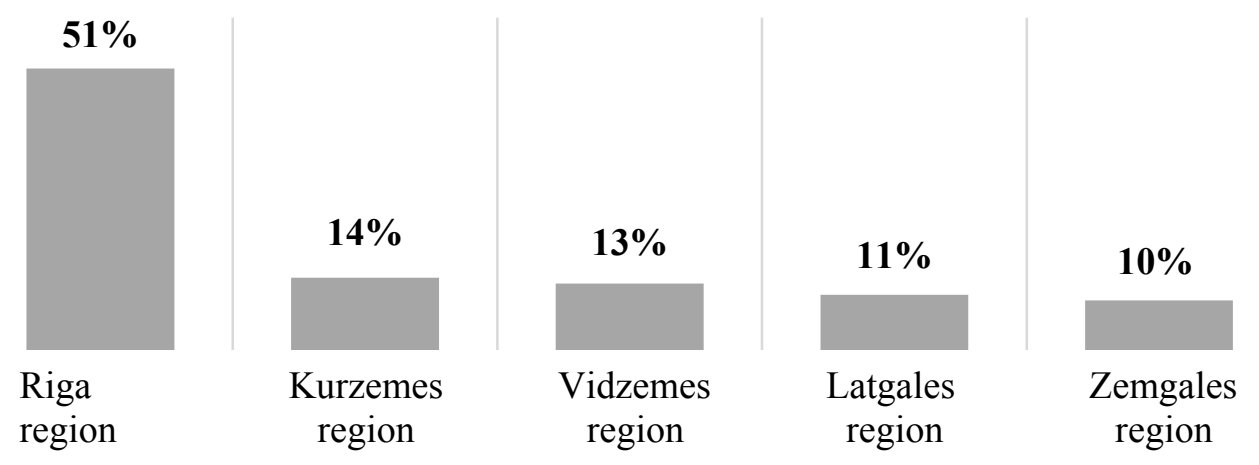

Figure 1. The division of respondents by regions

After collecting the statistical data a conclusion has been made that most answers have been obtained from the respondents in Riga region (51\%), followed by Kurzemes region (14\%) and Latgales region (13\%), while the least number of responses has been obtained from Zemgales and Vidzemes regions (see Figure 1). 


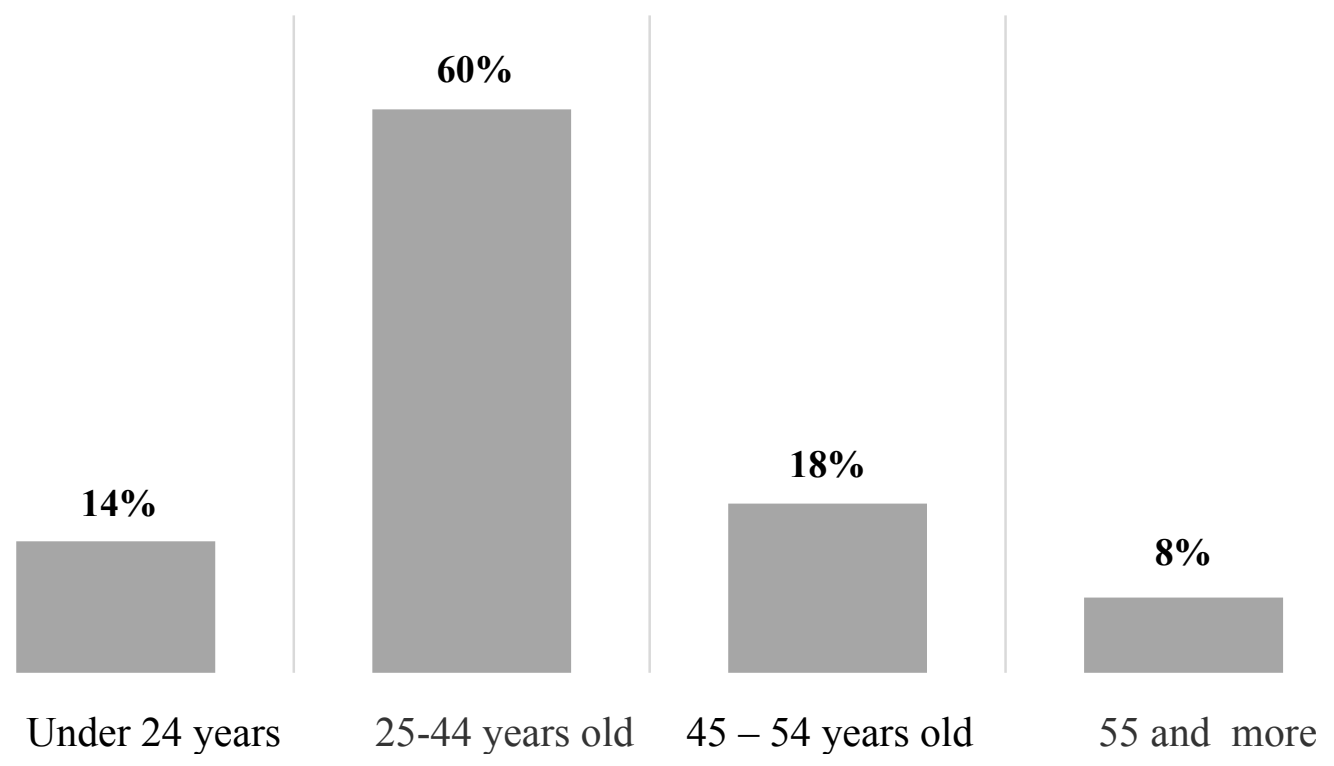

Figure 2. The division of respondents according to age groups

By analysing the divisions of age groups, respondents are divided in the following way: under 24; 25 - 44 years old; 45 - 54 years old; 55 and older (see Figure 2). $60 \%$ of all the respondents are between the ages $25-44,14 \%$ - under the age of $24,18 \%$ - between the ages $45-54,8 \%$ - 55 and older.

By analysing the data according to the time period, how long the respondent has had a status of the unemployed or a job seeker (see Figure 3), the most $-78 \%$ respondents have had the status of the unemployed or a job seeker up to 1 year, $15 \%$ - from 1 - 3 years, $6 \%$ - more than 3 years.

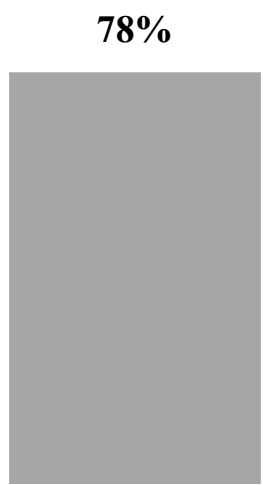

Up to 1 year

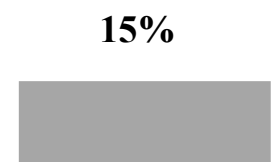

From 1 - 3 years

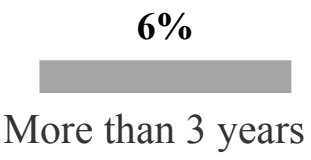

More than 3 years

Figure 3. The division of respondents according to the time period of registration in the Agency

The data of the estimated usefulness of the career counselling have been analyzed. As it can be seen in Figure 4, 27\% of the respondents consider career counselling as a useful service, evaluating it as high. $21 \%$ of the respondents 
evaluate the usefulness of the career counselling as low, while $13 \%$ of the questioned consider this kind of service as useless.

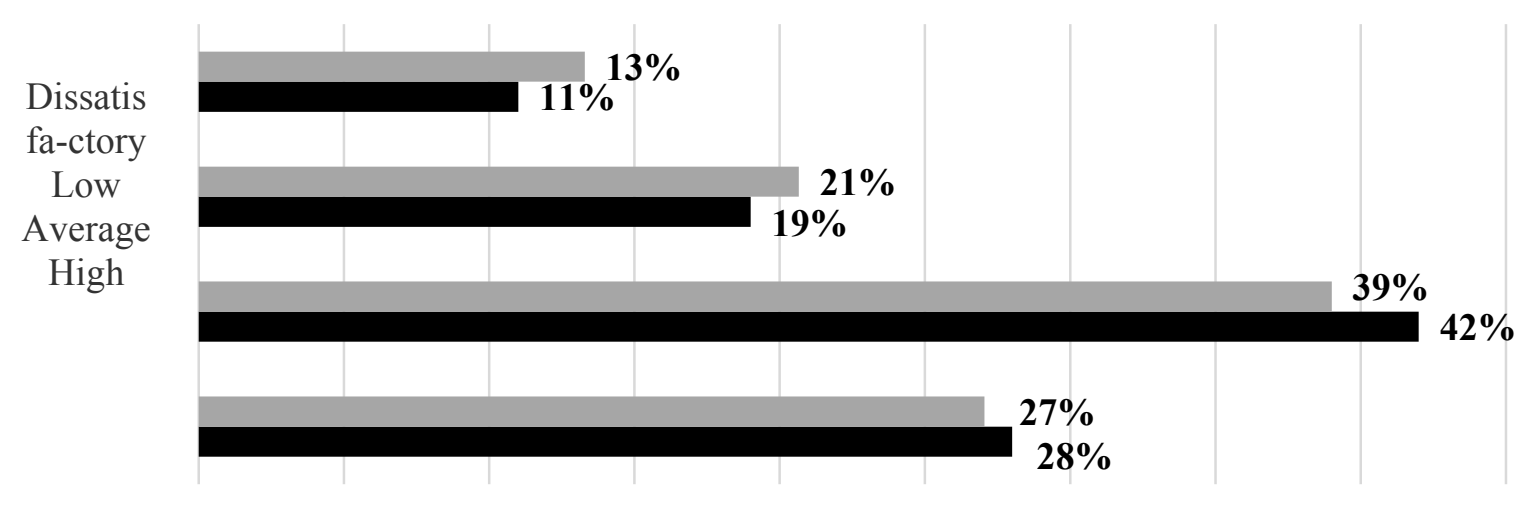

$\square 2014 \square 2013$

Figure 4. The estimation of the usefulness of career consultations

By making the comparison of survey data with the data obtained in 2013, it can be concluded that in 2014 the number of respondents has increased by $2 \%$, who consider that the usefulness of career counselling in the Employment Agency is not very high. In the surveys of both years 2013 and 2014 the respondents evaluate the usefulness of the Agency services in the process of looking for a job, and it can be concluded that in comparison with the year 2013 the indicators of usefulness have decreased for all the events also in 2014. For example, the usefulness of career counselling has decreased by $4 \%$, the usefulness of the events for increasing competitiveness has decreased by $4 \%$, the usefulness of the offer of continuing vocational training and professional development programme of education for the unemployed has decreased by $5 \%$, the acquisition of non-formal education has decreased by $2 \%$.

In order for career counselling to maintain topicality and be able to satisfy the needs of help-seekers in the modern society, it is concluded that also the career counselling has to change - both in terms of the words and the methods used. According to the obtained theoretical knowledge about the career guidance for the unemployed, the work of career counsellors has to be improved, by differentiating the system of career counselling according to the groups of clients, as in the circumstances of developing a knowledgeable society the people's creativity, critical thinking, problem solving, decision making for acquiring new skills should be promoted, in order to live in the modern progressive world.

\section{Discussion and conclusions}

By studying different career theories (McClelland, Super, Holland, Erikson, Parson, Rogers, Viljamson, Klimov, Jung, Peavy, Bandura, Fukuyama and others), which are focused on the achievement motivation of the 
unemployed, lifelong career, choice of profession theory, socio-dynamic constructivity theories and methods, the acquired knowledge would contribute to the assistance of the clients of the State Employment Agency, thus decreasing their problems of work and simultaneously strengthening their ability to choose and act responsibly towards oneself, by setting individual aims.

By integrating the career theory conclusions into the science of pedagogy, by identifying the promoting and the inhibiting factors of the career, during the process of the employment agency services it becomes possible to look for and make use of those pedagogical organization forms and methods, which would ensure the formation of certain habits of activities, thus creating pedagogical preconditions also for a more successful career development.

In the course of the research a contradiction was found out between the fact that the value of education is recognized in the adult society and the fact that the unemployed in the adulthood lack the necessary knowledge for making and developing their careers.

By developing and improving the career and adult education as constituents of lifelong learning, which are joined by the necessity to ensure the continuity of lifelong learning and the career development, the career services are the creation of circumstances and conditions for continuous development of the personality in its living, working and learning environment.

There is a situation that the skills demanded by the labour market are limited. The number of the available jobs is very low, so the people have to be flexible and have to be able to adapt their skills.

The person's need for education can be stimulated not only by various outer socio-economic or political factors and stimuli, but also by the inner motives and needs.

By viewing different insights made by scientists about the opportunities of giving career services, it can be concluded that career is different for each person, it is dynamically developing throughout the lifetime. The career reflects the person's ability to find balance between the paid and unpaid work, as well as the duties of private life.

In order for career counselling to maintain topicality and be able to satisfy the needs of help-seekers in the modern society, also the career counselling has to change - both in terms of the words and the methods used.

According to the obtained theoretical knowledge about the career guidance for the unemployed, the work of career counsellors has to be improved, by differentiating the system of career counselling according to the groups of clients, as in the circumstances of developing a knowledgeable society the people's creativity, critical thinking, problem solving, decision making for acquiring new skills should be promoted. 


\section{SOCIETY. INTEGRATION. EDUCATION. Volume IV}

\section{References}

Centrālās statistikas pārvalde, (2014). Darbaspēka apsekojuma galvenie rādītāji 2001.2013.gadā: Informatīvais apskats. [online] [15.02.2015]. Downloaded from http://www.csb.gov.lv/sites/default/files/nr_17_darbaspeka_apsekojuma_galvenie_raditaji_lat vija_2001-2013_gada_2014_00_lv.pdf.

Eiropas Komisija, (199̄8). Baltā grāmata par izglìtību un apmācību. R.: APA.

Garleja, R. (2006). Cilvēkpotenciāls sociālā vidē, Izdevniecība RaKa, 199 lpp.

Holland, J. L. (1997). Making vocational choices: a theory of vocationalpersonalities and work environments (3rd ed.). Odessa, FL: Psychological Assessment Resources, 303 p. [online] [15.02.2015]. Downloaded from http://www.pkc.gov.lv/images/ NAP2020\%20dokumenti/20121220_NAP2020_apstiprinats_Saeima.pdf

In D.Brown \& L. Brooks (Eds.), Career choice and development. San Francisco: JosseyBass.,p. 197- 261.

Jaunzeme, I. (2013). Karjeras attīstības atbalsta sistēmas darbības izvērtējums Latvijā. [online] [12.02.2015]. Downloaded from http://www.viaa.gov.lv/files/news/19710/ p_t_jums_emkapt_kaas.pdf).

Koķe, T. (2011). 21.gs. kompetences dzīves kvalitātei. [online] [12.02.2015]. Downloaded from ,http://www.lvg.lv/upload/Konference/materiali/Prof_Koke1.pdf.

Koķe, T. (1999). Pieaugušo izglìtības attīstība: raksturīgākās iezīmes. R.: Mācību apgāds.

Korna, E. (2011). Karjeras izglītība. Rīga: RaKa, 234 lpp.

Latvijas Brīvo arodbiedrību savienība. (2013). Starptautiskās Darba konferences 102.sesija un sociālā dialoga komitejas ziņojums. [online] [14.02.2015]. Downloaded from http://www.lbas.lv/upload/stuff/201307/sdo.102.konference.socialais.dialogs_mickevica_31.0 5.2013 final.pdf.

Latvijas Republikas Saeima. (2010). Latvijas ilgtspējīgas attīstības stratēgija līdz 2030. gadam "Latvija 2030". [online] [16.02.2015]. Downloaded from http://baltadaba.lv/wpcontent/uploads/2013/04/latvija2030_lv.pdf

LR Ekonomikas ministrija, (2014), Informatīvais ziņojums par darba tirgus vidēja un ilgtermiņa prognozēm. [online] [16.02.2015]. Downloaded from https://www.em.gov.lv/ lv/nozares_politika/tautsaimniecibas_attistiba/informativais_zinojums_par_darba_tirgus_vide ja un ilgtermina prognozem/.

LR Saeima. (2012). Latvijas nacionālais attīstības plāns 2014-2020.gadam. [online] [17.02.2015]. Downloaded from http://www.pkc.gov.lv/images/NAP2020\%20dokumenti/ 20121220_NAP2020_apstiprinats_Saeima.pdf

LR Saeima. (2014). Izglītī̄bas attīstības pamatnostādnes 2014.-2020.gadam. [online] [17.02.2015]. Downloaded from http://likumi.lv/doc.php?id=266406.

Miķelsone, I \& Latsone, L. (2008). Karjeras atbalsta un teoriju attīstība Rietumu valstīs. D.Lieǵgenieces \& A.Lasmanes redakcijāa, Karjeras attīstības atbalsts ( 64-107 lpp). Jelgava: SIA Jelgavas tipogrāfija.

Padomes Rezolūcija par atjaunotu Eiropas izglītības programmu pieaugušajiem, Eiropas Savienības Oficiālais Vēstnesis, (2011). [online] [18.02.2015]. Downloaded from http://izm.izm.gov.lv/upload_file/2013/Eiropas_Izgl_progr_pieaug.pdf

P̄̄vijs,V. (2010). Sociodinamiskā konsultēšana: praktiska pieeja nozīmesveidošanai. Šagrinfolza, Ohaio.Taosas institūta izdevniecība.

Savickas, M. L. (2005). The theory and practice of career construction. In S. D. Brown $\&$ R. T. Lent (Eds.), Career development and counseling: Putting theory andresearch to work. Hoboken, NJ: Wiley, pp. 42-70.

Super, D. E. (1990). A life-span, life-space, approach to career development. 